\title{
Comparing the Applications of Management Accounting between Vietnamese Public Universities by the Degree of Autonomy
}

\author{
Oanh Thi Tu LE $P h D$ \\ University of Labour and Social Affairs, Hanoi, Vietnam \\ E-mail: oanhletu@gmail.com \\ Phong Thi Thu Tran \\ Hanoi Open University, Vietnam \\ E-mail: thuphonghou@gmail.com
}

\begin{abstract}
This study was conducted based on a survey of 53 public universities in Vietnam to evaluate the applications of management accounting in universities according to the following metrics: (i) Cost classification; (ii) Conducting and evaluating budgets; (iii) Management responsibility; and (iv) Using information to make short-term and long-term decisions. The results showed that public universities have some interest in management accounting information, especially responsibility accounting. However, management accounting information which has not been used much in Vietnamese universities includes controllable and uncontrollable costs and variance analysis between actual results and estimates. Regarding the degree of autonomy, fully or partially autonomous universities tend to apply management accounting more than non-autonomous universities in terms of the cost per student, the fees for repeat classes, and management responsibility. The research results showed the need to use management accounting information when universities increase their autonomy.
\end{abstract}

Keywords: Management Accounting, Public Universities, Autonomy, Vietnam.

JEL Classification: M40, M4I, M49.

\section{Introduction}

The system of public universities plays an important role in the economics of each country by the higher education system development. Along with the international integration trend, higher education is changing rapidly in all ways. University autonomy is inevitable for the development of education and training. Therefore, universities in general and public universities in particular need to constantly improve the quality of training and branding. Public universities are state-owned training institutions which are funded by the state budget to establish, finance operations. The activities of public universities must comply with the principles of authorized state agencies ( Vu, 2017).

University autonomy is the freedom of a higher education institution for its operations neither the management nor influence of the government (Anderson \& Johnson, 1998). According to Vietnam's Education Law (2005) university autonomy includes regulations on personnel, academic autonomy and finances. The degree of university autonomy is associated with the model of autonomy and is always changing to suit the socio-economic context of each country (Nguyen, 2020). The models of autonomy classify different degrees of autonomy including (I) non-autonomous (state control); (2) semi-autonomous and (3) independent. As of December 2018, Vietnam had I7I public universities (accounting for $72.45 \%$ of the total number of universities) (Nguyen, 2020). Facing the challenge of fierce competition of international integration, public universities in Vietnam have been given autonomy in their operations. The assignment of university autonomy was stipulated in the Vietnam's Education Law (2005) conducted under Resolution 77/NQ-CP issued on October 24, 2014 on Piloting the renovation of public tertiary during 2014 - 20I7. Furthermore, the Decree I6/2015/ND-CP of the Government which stipulates the autonomy mechanism of public institutions has marked a change in management goals of public university. According to this Decree, the right of autonomy and self-responsibility of public universities includes (i) performing tasks; (ii) organizational structure and personnel; (iii) financial autonomy. Autonomy in performing tasks includes the right to identify the missions, the visions, and autonomy in recruitment activities, training, scientific research and international cooperation. Autonomy in organizational structure and personnel presents in the freedom to recruit, manage and use employees. Financial autonomy means that a university has to take responsibility for finance issues, generate revenues and use financial resources instead of being granted by the State. Recently, according to a report of the Ministry of Education and Training (2018) university autonomy has made positive changes such as reducing administrative procedures, increasing initiative and flexibility in the implementation of universities' activities. This transformation does not only stem from the objective demands and the change of the environment of education but it is also motivated by the regulations and policies issued by the Party and the Government. 
Thus, by shifting from a state control model to a more autonomous model, public universities must operate more effectively and efficiently. Management accounting is one of the effective tools to help university administrators to have timely, complete and predictive information to support decision making (Truong, 2010). Management accounting has shifted from providing simple information to providing information for short-term and long-term decision-making. Purpose of management accounting is to improve operational efficiency and profitability by providing information for planning, controlling, and decision making (Sunarni, 2013).

Vietnam has overcome many difficulties since 1986, the Innovation time and has accomplished great achievements of historical significance (Le et al., 2020). The third and fourth industrial revolutions have brought not only tremendous opportunities, but also significant challenges. The 4.0 revolution has brought Vietnam opportunities for development in all economic, cultural and educational fields. Vietnam's education in general has achieved the certain achievements and (Le, 2020). The university autonomy is indispensable to fit the challenges. This process still has many shortcomings that need to be improved. The paper aims to compare differences in the applications of management accounting among public universities in Vietnam by the degree of autonomy.

\section{Literature Review}

The applications of management accounting and changes of information regarding the assignment of autonomy in universities have received attention from many researchers.

Le (2017) considered management accounting as a tool for financial autonomy in public universities. The author proposed the classification of variable costs and fixed costs; identified cost objects according to training level and training system; assessed the impact of cost fluctuation on financial performance of the school.

Yasmiza et al. (2017) analyzed the role of management accounting in Malaysian public universities. The research showed that administrators of Malaysian Universities were interested in the most important types of accounting information including reports, budgets and strategic management accounting. The research also showed that teamwork and willingness to take responsibility are the most demanding skills of accounting in Malaysian public universities.

The research on management accounting in public universities was investigated current situation of responsibility accounting in Ugandan public universities (Owino et al., 2016). The study found that there existed responsibility accounting systems in public universities in which costs and revenues were accrued and reported from faculty and from faculty to university management, the head of the department has the authority to manage their estimates of budget allocation. However, responsibility accounting which follows the model of decentralization in public universities is not emphasized. The reporting system of public university is mainly formal, which affects the use of information of the Board of Directors to make decisions.

Agasisti \& Johnes (2010) investigated the evaluation of efficiency in Italian universities in the rapid changes of higher education environment in Europe when the government delegated financial autonomy to universities. Research results showed that changes in cost structure and technical efficiency reduce profitability in universities.

Horne \& Hu (2008) evaluated the performance of Australian universities. By estimating the cost-effectiveness of 36 universities in the period of 1995-2002 by random marginal analysis, the results showed that universities do not work effectively when evaluating the use of costs. Therefore, it suggested assigning responsibility to individual managers to have better costs control.

Agasisti \& Johnes (2010) evaluated the strategic management accounting in four major Italian universities in the rapidly changing environment of European universities from the mid-1980s when the government gave financial autonomy to universities. This change created challenges for administrators and accounting systems of universities. The study analyzed and recommended strategic management accounting for these universities in two aspects of resource allocation and new training programs.

Cropper \& Cook (2010) pointed out that many universities are not satisfied with their cost accounting systems and are seeking ways to change them. As financial resources of universities become more limited due to financial autonomy, it is necessary for universities to offset the costs with the revenue from training courses to better manage resources.

Thus, the above studies have shown the importance of management accounting for universities in the context of the economy movement, the requirements of implementing autonomy mechanism. Researches have also shown a link between management accounting information and the application of management accounting techniques to improve universities performance. To assess if there is a difference in management accounting by the degree of autonomy has not been mentioned and this is an urgent issue for Vietnam while implementing the transition from state management to implement university autonomy.

\section{Methodology}

The study was conducted through sending questionnaires via email to I38 universities in Vietnam. The questionnaire was divided into 5 main parts: (i) Identification of operating costs; (ii) Budgeting activities; (iii) Assessment of management responsibility; and (iv) Using information in decision making; (v) Information of public university. The identification of operating costs was conducted using Yes/ No questions. The remaining questions used 5 -point Likert scale, in which $\mathrm{I}=$ Strongly disagree and $5=$ Strongly agree. 
Table I. Autonomy Degree

\begin{tabular}{lcc}
\hline Autonomy Degree & $\mathrm{N}$ & $\%$ \\
\hline Non autonomy & 8 & $\mathrm{I} .1 \%$ \\
\hline Semi autonomy & 29 & $54.7 \%$ \\
\hline Full autonomy & $\mathrm{I} 6$ & $30.2 \%$ \\
\hline Total & 53 & $\mathrm{I00} \%$ \\
\hline
\end{tabular}

Source: Compiled by the authors based on research results

Regarding characteristics surveyed public universities (Table I), the number of questionnaires sent was I38, and the number of answers received was 53 that are equal to $40 \%$ in the response rate. The number of samples needed to conduct the study is 4I (Nguyen \& Nguyen, 2015) at this rate, so the collected sample is sufficiently reliable to implement the research. Out of 53 surveyed universities, I6 were fully autonomous (30.2\%), 29 were semi-autonomous $(54.7 \%)$ and 8 universities were not autonomous. The structure of the surveyed universities is suitable for analysis because Vietnamese public universities are in the process of becoming fully autonomous. The number of non-autonomous universities is less than the number of autonomous.

Table 2. Years of establishment

\begin{tabular}{lcc}
\hline Years of establishment & $\mathrm{N}$ & $\%$ \\
\hline$<\mathrm{I0}$ years & 3 & $5.7 \%$ \\
\hline $10-20$ years & 9 & $\mathrm{I} 7.0 \%$ \\
\hline $20-50$ years & $\mathrm{I} 6$ & $30.2 \%$ \\
\hline$>50$ years & 25 & $47.2 \%$ \\
\hline Total & 53 & $\mathrm{I} 00 \%$ \\
\hline
\end{tabular}

Source: Compiled by the authors based on research results

In terms of number of years of establishment (Table 2), most of surveyed universities had been established for over 50 years $(25 ; 47.2 \%)$. The next most common group was universities which had been established for between 20 and 50 years (16; 30.2\%). The rest were universities which had been established for less than 20 years. Specific characteristics of Vietnamese public universities established early, with a long history of establishment and development.

Table 3. Location of university

\begin{tabular}{llc}
\hline Location & $\mathrm{N}$ & $\%$ \\
\hline Northern & 30 & $56.6 \%$ \\
\hline Central & $\mathrm{II}$ & $20.8 \%$ \\
\hline Southern & $\mathrm{I} 2$ & $22.6 \%$ \\
\hline Total & 53 & $\mathrm{I} 00 \%$ \\
\hline
\end{tabular}

Source: Compiled by the authors based on research results

Regarding location, the majority universities were located in the North of Vietnam (30;56.6\%). The number of universities located in the Central and the South of Vietnam were relatively equal (the rates are $20.8 \%$ and $22.6 \%$ respectively (Table 3). Regarding region, out of 138 public universities in Vietnam, the number of universities in the North accounted for 54\%; the number of universities in the Central took up 20\% and the number of universities in the South accounted to $27 \%(\mathrm{Vu}, 2017)$. The distribution rate of the sample of 53 public universities surveyed is equivalent to the overall.

\section{Research Results}

\section{I Cost Classification}

Identifying the type of cost is always an important content of management accounting since it is the basis for evaluating and analyzing the effectiveness of cost control and providing information for managers to make decisions. Therefore, the survey used the Yes/No questions to investigate the current situation of cost classification of universities based on the following classifications: (I) Variable and fixed costs; (2) Direct and indirect costs per student; (3) Direct and indirect 
costs per faculty or department; (4) Cost factor (salary, scholarship, outside services); (5) Controllable and uncontrollable costs. The results are shown in Figure I.

Figure I. Comparing the cost classificaion

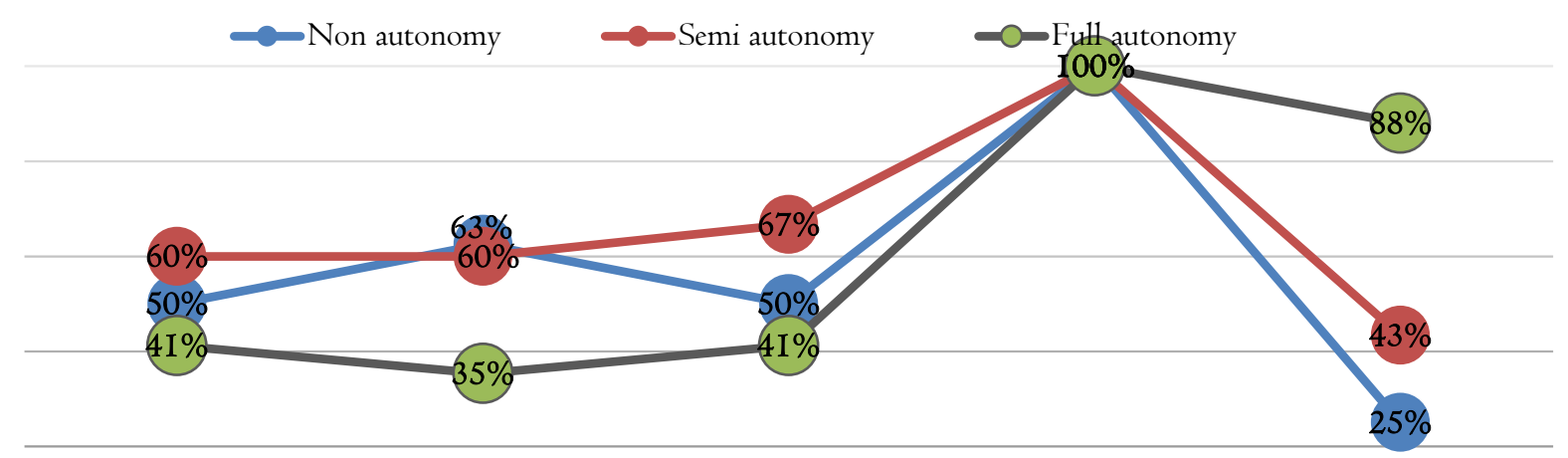

$\begin{array}{cccc}\begin{array}{c}\text { I. Variable costs and } \\ \text { fixed costs }\end{array} & \begin{array}{c}\text { 2. Direct and indirect } \\ \text { costs/student }\end{array} & \begin{array}{c}\text { 3. Direct and indirect } \\ \text { costs/department }\end{array} & \begin{array}{l}\text { 4. Factor Costs } \\ \text { 5. Controllable and }\end{array} \\ \text { uncontrollable costs }\end{array}$

Source: Compiled by the authors based on research results

According to Figure I, all universities had implemented cost classification by factor. However, non-autonomous universities and partially autonomous universities are more interested in variable costs and fixed costs, direct and indirect costs (from $50 \%$ to $70 \%$ ) than fully autonomous universities are (40\%). In contrast, fully autonomous universities tend to keep track of controllable and uncontrollable costs more than the other two groups do $(88 \%)$.

\subsection{Conducting and Evaluating Budgets}

Budgeting is a mandatory step for public universities to make reports to the government. Therefore, $100 \%$ of public universities make annual budgets for this purpose. However, from the perspective of management accounting, the cost budgeting is for the purposes of cost control, comparing actual results with estimates; evaluating cost budgets by division (faculty, department); analysis of variances according to price and quantity factors; finding causes of variances to adjust for future budgeting. The survey used the 5-point Likert scale (from "Strongly disagree" to "Strongly agree") and compared mean values, actual budgeting situation of public universities. The results are shown in Figure 2.

\section{Non autonomy $\quad-$ Semi autonomy $\quad-$ Full autonomy}

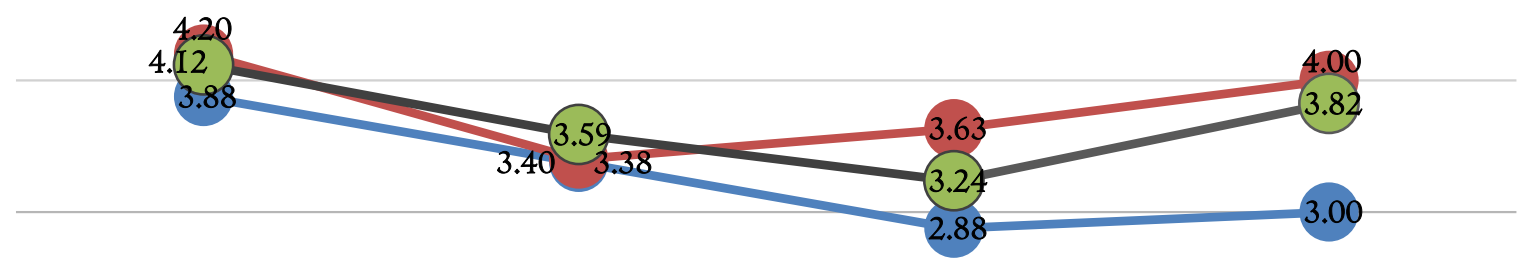

I. Estimates and actual variances (entire university)
2. Estimates and actual variances (each department)
3. Factor variance analysis 4. Finding the varianve cause

Figure 2. Comparing budgeting by the degree of autonomy

Source: Compiled by the authors based on research results 
Figure 2 indicates that, in general, partially and fully autonomous universities tend to implement more budgets than non-autonomous universities. Specifically, variances between the estimates and actual results (the entire university, each department) among these 3 groups of universities are relatively similar, (mean values ranging from 3.4 to 4.12 , which correspond to a score of "agree"). There is a significant difference regarding variance analysis by factor and cause among 3 groups of universities, in which, partially and fully autonomous universities had similar results (mean values ranging from 3.8 to 4.0 ), non-autonomous universities had the lowest mean value.

\subsection{Management Responsibility}

The management responsibility in public universities refers to the decentralization, the level of responsibility assigned to each department, the individual in charge of the department, thereby helping to control operational efficiency. To find out the difference in the management responsibility by the degree of autonomy of universities, a comparison of mean values were made. The results are shown in Figure 3.

$\longrightarrow$ Non autonomy $\longrightarrow$ Semi autonomy $\longrightarrow$ Full autonomy

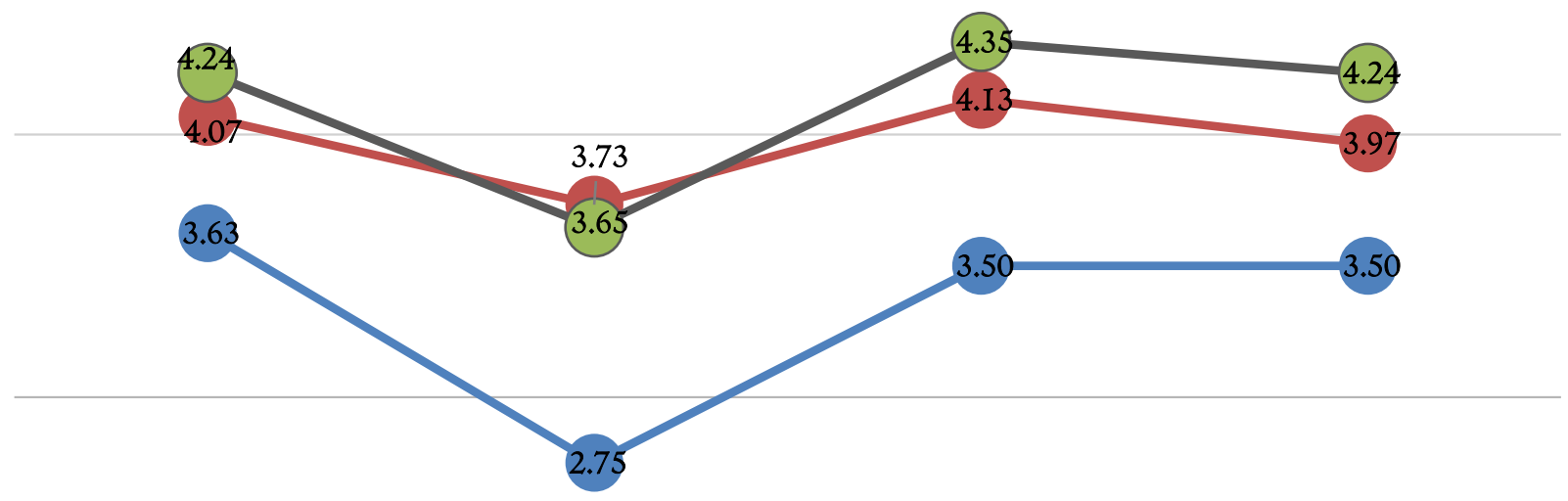

I. Obvious management decentralization
2. Assign responsibility to segment
3. Assign responsibility to 4. Leaders responsible for their service centers

Figure 3. Comparing management responsibility

Source: Compiled by the authors based on research result

The group of non-autonomous universities had lower mean values regarding the management responsibility (mean values ranging from 2.7 to 3.63) (Figure 3). Particularly, the assignment of cost responsibility to each department and individual in charge of each department had not received much attention. Partially autonomous universities and fully autonomous universities had relatively similar results. Specifically, partially autonomous universities had slightly higher mean values, especially regarding the responsibility to service centers. 
$\longrightarrow$ Non autonomy $\longrightarrow$ Semi autonomy $\quad$ Full autonomy

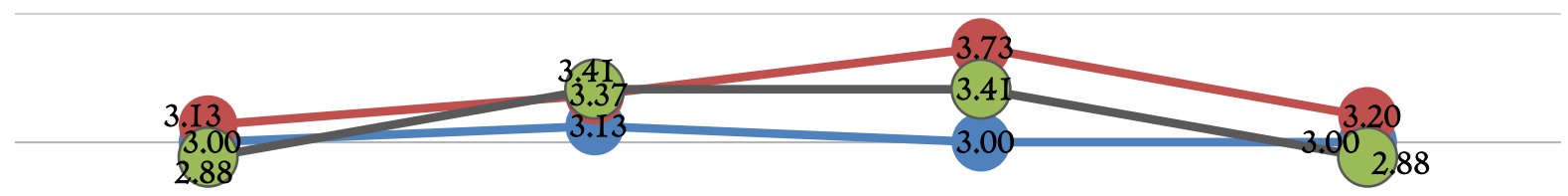

I. Controllable and uncontrollable costs / profits
2. Segment profit

3. Residual Income (RI)

4. Return on investment

(ROI)

Figure 4. Comparing the evaluation criteria

Source: Compiled by the authors based on research results

Base on criteria used to evaluate performance including controllable and uncontrollable costs/profits, segment profits, RI, ROI (Figure 4), groups of universities had similar results with mean values of approximately 3.0. The partially autonomous universities and partially autonomous universities had higher mean values than non-autonomous universities. Partially autonomous universities used these criteria the most (mean from 3.13 to 3.37). Autonomous universities tend to use these criteria less.

\subsection{Information for Decision Making}

Regarding the use of management accounting information in making short-term decisions, $100 \%$ of universities' leaders used management accounting information. The basic information used include breakeven point, class size, cost per student, implementation of joint training programs, tuition fees for short-term training courses, wage per teaching hour. A comparison of the use of information in decision making by the level of autonomy in is shown in Figure 5.

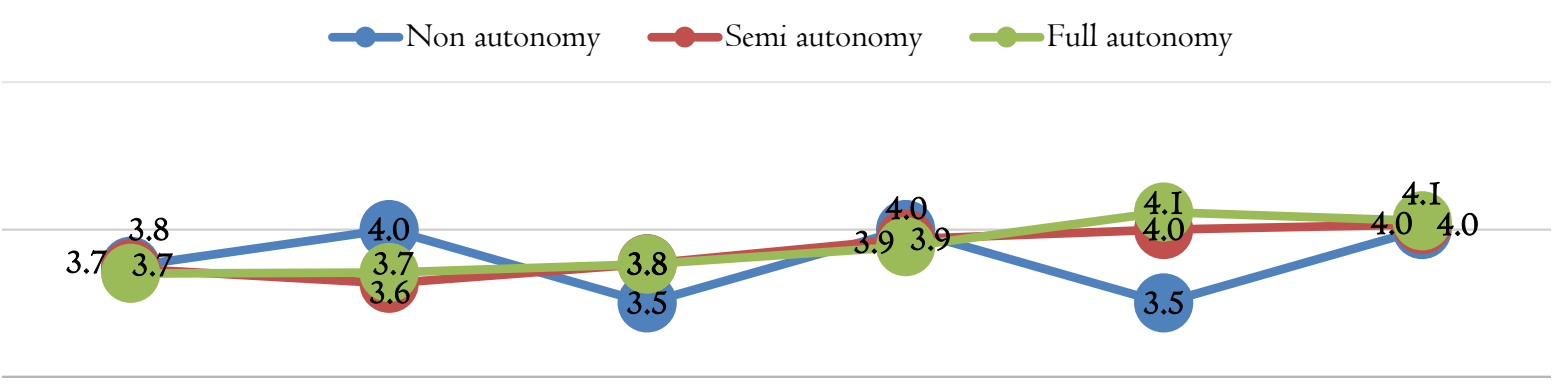

\begin{tabular}{ccccc}
\hline $\begin{array}{c}\text { I. Breakeven point } \\
\text { / course }\end{array}$ & $\begin{array}{c}\text { 2. The again class } \\
\text { scales }\end{array}$ & $\begin{array}{c}\text { 3.Unit cost per } \\
\text { student }\end{array}$ & $\begin{array}{c}\text { 4. Joint training } \\
\text { 5. Short-term } \\
\text { tuition fees }\end{array}$ & $\begin{array}{c}\text { 6. Unit price of } \\
\text { lecture hours }\end{array}$
\end{tabular}

Figure 5. Comparing the use of information in making short-term decisions

Source: Compiled by the authors based on research results 
Universities were relatively consistent when using the information to make decisions about the breakeven point analysis, wage per teaching hour and joint training programs (mean values ranging from 3.7 to 4.0 , which correspond to a score of "agree") (Figure 5). Fully autonomous universities tend to use management accounting information to make decisions more than the other two groups. Partially autonomous universities and fully autonomous universities had similar results. The only significant difference is using information for making decisions about short-term training courses. Nonautonomous universities used such information to varying degrees. Particularly, they used the information to determine the class size joint training programs more than the other two groups and used the information about the cost per student and tuition fees of short-term courses less than the other two groups.

When comparing the use of information for making long-term decisions such as the balanced scorecard, activitybased costing or responsibility accounting (Figure 6), groups of universities had relatively similar results (mean values ranging from 3.5 to 4.1 ). Responsibility accounting information was used the most, which was followed by activity-based costing. All groups did not support the balanced scorecard. Fully and partially autonomous universities used this information more than non-autonomous universities.

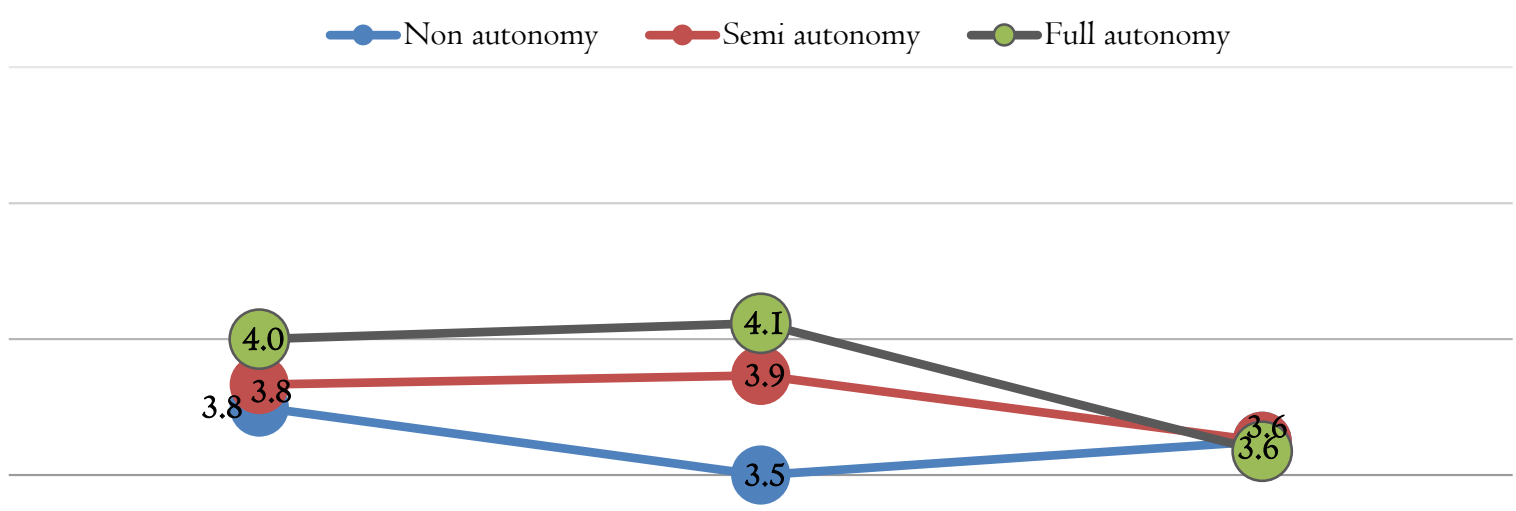

I. Responsibility accounting
3. Balance Score Card

Figure 6. Comparing the use of information in making long-term decisions

Source: Compiled by the authors based on research results

\section{Discussion and Conclusion}

Study on the applications of management accounting in public universities according to the degree of autonomy reflect the similarities of universities that they implement cost classification by factors, make annual budgets, compare the variance between the estimates and actual results. In addition, the Board of Administrators attaches great importance to management accounting information to make decisions. However, three groups of universities also had certain differences, namely:

Regarding cost classification, controllable and uncontrollable costs which are essential in cost control are used more by fully autonomous universities than the other two groups. However, fully autonomous universities did not pay much attention on cost classifications to prepare reports for decision making. Namely, variable costs and fixed costs are used to make decisions regarding additional options; direct and indirect costs per student serve as a basis for determining breakeven points for training courses, training majors, joint programs; Direct and indirect costs for each department serve as a basis for decision making, cost control for each department, faculty, and unit.

Regarding budgeting, fully autonomous and partly autonomous universities pay more attention on variance analysis by factors and finding the causes than non-autonomous universities. This limits the provision of appropriate information to find nature of the differences, responsible individuals or departments to make necessary adjustments in the next accounting period.

In terms of management responsibility, autonomous universities (fully and partially) had similar assessments of management responsibility. However, they rated the management responsibility higher than non-autonomous universities. Particularly, fully autonomous universities had the highest assessment of those management responsibilities, especially responsibility to service centers, which indicates that the autonomy requires universities to have efficient use of finances. The results of performance evaluation criteria are similar. Specifically, fully and partially autonomous universities used evaluation criteria more than non-autonomous universities. The assignment of rights and responsibilities will help service centers improve their performance. 
In terms of the use of relevant information relevant for decision making, fully autonomous universities tend to provide and use more management accounting information. This means that management accounting information is more useful to the administrators when universities shift to the autonomy mechanism. Non-autonomous universities provide information inconsistently. Regarding information for making long-term decisions, the balanced scorecard is still a complex method that had not been used much by universities compared to responsibility accounting. With the autonomy mechanism, public universities in Vietnam had paid great attention to responsible accounting information.

The results reflected characteristics of Vietnam universities in transition from the state's funded mechanism to autonomy. Although universities need changes to adapt and improve the effectiveness, employees are no changes and their thinking still has the influence of the protection mechanism. This change needs a process. On the other hand, management accounting in universities is still quite new in Vietnam. Without autonomy, universities are used to providing information according to the requirements of the state, which is stereotypical. Therefore, the importance of information in decision making has not been given. Information on costs, cost classifications, variance analysis on implementation and budget for the adjustment in the next period, assigning management responsibilities to each department on costs and revenue, costvolume-profit analysis ... have not really been paid attention. When shifting to autonomy, universities must operate as businesses, self-balancing finance and management accounting. The comparison of the application of management accounting between Vietnamese Universities by the degree of autonomy has been different. Accordingly, fully autonomous universities have focused on applying management accounting more than partially autonomous ones, while partly autonomous universities have also applied the management accounting better compared to non-autonomous universities. This finding indicates the necessity of using management accounting information when public universities are given autonomy.

\section{References}

Agasisti, T., \& Johnes , G. (2010). Heterogeneity and the Evaluation of Efficiency: the Case of Italian Universities. Applied Economics, 42(II), I365-I375.

Anderson, D., \& Johnson, R. (1998). University Autonomy in Twenty Countries.

Cropper, P., \& Cook, R. (2010). Developments: Activity-Based Costing in Universities-Five Years On. Public Money \& Management, 20(2), 6I-68.

Horne, J., \& Hu, B. (2008). Estimation of cost efficiency of Australian universities. Mathematics and Computers in Simulation, 78(2-3), 266-275.

Le, D. Q. (2017). Management accounting - the tool to implement financial autonomy at public universities. Finance Magazine, Part, I6, 78-79.

Le, T. Q. (2020). Orientation for an Education . A New Vision for Future Education in Vietnam. International Journal of Innovation, Creativity and Change, II(3), 5I3-526.

Le, T. Q., Bui, M. T., \& Phung, L. T. (2020). Application of Change Management Theory to Command New Teaching Activities in High Schools. International Journal of Innovation, Creativity and Change, II(2), 557-568.

Ministry of Education and Training. (2018). Report on implementation of Resolution No. $77 / N Q-C P$.

Nguyen, M. T., \& Nguyen, H. V. (2015). Textbook of Survey Methods: Principles and practice. Hanoi: National Economics University Publishing House.

Nguyen, N. T. (2020). Financial autonomy when performing university autonomy - Research at University of Law, Hue University.

Owino, P., Munene, J., \& Ntayi, J. (2016). Does responsibility accounting in public universities matter? Cogent Business \& Management, 3(I), I-IO.

Sunarni, C. W. (2013). Management accounting practices and the role of management accountant: Evidence from manufacturing companies throughout Yogyakarta, Indonesia. Review of Integrative Business and Economics Research, 2(2), 616-626.

$\mathrm{Vu}, \mathrm{T} . \mathrm{T}$. (2017). Financial governance in Vietnamese public universities. Hanoi: Finance Publishing House, Vietnam.

Vietnam's Education Law. (2005). Education Law No.38/2005/QHII dated on 6/I4/2005.

Yasmiza, L., Ummi, H. J., Syamsul, R. A., \& Madya, I. A. (2017). Management Accountant Practice in Malaysian Public Sector. World Applied Sciences Journal, 35 (8), I482-I489.

\section{Copyrights}

Copyright for this article is retained by the author(s), with first publication rights granted to the journal. This is an openaccess article distributed under the terms and conditions of the Creative Commons Attribution license (http://creativecommons.org/licenses/by/4.0/). 